\title{
GENEOLOGI KEBIJAKAN DESENTRALISASI DARI KOLONIALISTIK HINGGA PASCAKOLONIALISTIK DEMOKRATIK DI INDONESIA
}

\author{
Mursyidin \\ Program Studi Sosiologi \\ Univerisitas Teuku Umar \\ Email: Mursyidin@utu.ac.id
}

\begin{abstract}
Decentralization has become one of the important phenomena that must be mentioned in the era of the last 10 years, where the great power of the central government in the past (precisely in the New Order era) has now been replaced with the introduction of regional autonomy, although this work is still being carried out, revised here and there, while we also see the phenomenon of more regional leaders (mayors, regents, or governors) who are suspected of corruption cases in various regions. Inevitably corruption becomes something decentralized too. In this situation, where is the position of the local press? Did he participate in guarding the existing democratization process, or did he also become part of the existing problem? Exactly whether we are talking about the role of the local press as a solution to the problem of corruption, or whether the local press is actually part of the problem of corruption.

Keywords: Decentralitation, Media, Local Politic
\end{abstract}

\section{A. PENDAhULUAN}

Kebijakan desentralisasi sejatinya bukan hal baru di Indonesia. Sejarah kebijakan desentralisasi di Indonesia ini telah mengalami perjalanan yang sangat panjang, tidak hanya semenjak lahirnya bangsa ini, tetapi sudah muncul sejak masa kolonial, meskipun pada saat itu, kata "desentralisasi" belum begitu popular seperti saat ini. Dalam rangka mewujudkan kepentingan pemerintah kolonial maka pemerintahan pun dibentuk. Pada waktu itu, gagasan ini bukan semata-mata untuk meningkatkan kapasitas politik masyarakat setempat, apalagi untuk kepentingan pengembangan demokrasi sebagaimana yang menjadi argumentasi kontemporer bagi perlunya penyelenggaraan pemerintah daerah. Ada juga pandangan yang menyatakan bahwa kebijakan desentralisasi juga didorong oleh komitmen politik etis pemerintah kolonial. Pendapat itu sebenarnya agak sulit diterima, pasalnya penyelenggaraan pemerintah daerah bukan untuk memajukan masyrakat setempat, tetapi lebih merupakan keinginan pemerintah kolonial guna mengeskpoitasi wilayah jajahan. Alasan ini diperkuat dengan kenyataan bahwa pada mulanya, Reglement (Staatsblaad 1855 No. 2) yang mengatur penyelenggaraan pemerintahan kolonial tidak mengenal desnetralisasi (The Liang Gie, 1993). 
Baru pada tahun 1903 pemerintah kolonial mengeluarkan Decentralisatiewet yang memberi peluang dibentuknya satuan pemerintahan (gewest) yang mempunyai keuangan sendiri. Penyelenggaraan pemerintah diserahkan pada sebuah Raad atau dewan di masing-masing daerah. Decentralisatiewet ini kemudian diperkuat dengan Decentralisatiebesluit dan Locale Radenordonanntie yang menjadi dasar terbentuknya "Locale Resort" dan "Locale Raad". Akan tetapi pemerintah daerah hampir tidak mempunyai kewenangan, dan bahkan anggota "Raad" ada yang sebagiannya diangkat, dan sebagian merupakan pejabat pemerintah, dan sebagian lagi yang dipilih. Hanya Raad di tingkat Gementee yang dipilih. Dewan daerah atau locale raad memang berhak untuk membentuk peraturan setempat yang menyangkut hal-hal yang belum diatur oleh pemerintah kolonial. Pengawasan terhadap pemerintah setempat dilaksanakan sepenuhnya oleh Governeur-General Hindia Belanda yang berkedudukan di Batavia.

Kemudian pada tahun 1922 pemerintah kolonial mengeluarkan sebuah undang-undang baru "Wet $O p$ De Bestuurshervormin” (S. 216/1992)/ dengan ketentuan yang baru ini maka kemudian dibentuk sejumlah "Provincie", "Regentschap" "Stadsgemeente" dan "Groepmeneenschap" yang semuanya mengantikan “Locale Ressort”. Pembentukan sejumlah daerah dilakukan dengan dikeluarkannya. “Ordonantie”, seperti Ordonnatie pembentukan Provincie Jawa Madura, Provincie West Java, Regemntschap Batavia. Sementara pulau-pulau di luar pulau Jawa dan Madura dibentuk melalui "Groepsemeenschaps Ordonantie”. Pemerintah sehari-hari di daerah dijalankan oleh Gouverneur untuk di Provincie, Regent Di Regentschap, dan Burgermeester di Gemeente.

Sementara itu selain pemerintahan bentukan baru tersebut., terdapat pula pemerintahan yang merupakan persekutuan asli masyarakat setempat yang oleh banyak kalangan disebut sebagai "Zelfbestuurende Landschappen”, yaitu persekutuan masyarakat adat yang oleh pemerintah kolonial tetap diakui keberadaannya, seperti dea di JAwa, Nagari Minang Kabau, Huta/Huria dan lain-lainnya di beberapa pulau di daerah Hindia Belanda. Untuk desa di JAwa kemudian diatur dengan Inlandsche GemmeenteOrdonantie (S. 83/1906) atau IGO, dan untuk masyarakat adat di luar Jawa di atur lebih lanjut dengan DesaOrdonatie (S. 356/1941) yang kemudian tidak sempat dilaksanakan berhubung terjadinya Perang Dunia ke II (The Liang Gie, 1993).

Selain administrasi pemerintah kolonial, pada masa itu terdapat pula administrasi pemerintahan kolonial, pada masa itu juga terdapat pula administrasi pemerintahan yang diselenggarakan oleh pemerintahan kerajaan yang sudah ada sebelum kedatangan kaum kolonial. Pemerintah kerajaan tersebut satu persatu diikat oleh pemerintah kolonial dengan sejumlah perjanjian atau Kontrak Politik baik yang bersifat kontrak panjang atau Lange Verklaring, dan Kontrak Pendek atau Korte Verklaring. Perbedaan di antara kedua jenis kontrak ini terletak pada pengakuan dari pemerintah kerajaan setempat. Dalam Lanmge Contract kekuaksaan pemerintah kolonial ditetapkan satu persatu dalam kontrak tersebut, dan yang diluar itu merupakan wewenang sepenuhnya kerajaan setempat. Kerajaan tang menjalankan Korte Verkalring 
mengakui kekuasaan pemerintah kolonial terhadap kerajaan tersebut dan berjanji untuk mentaati semua aturan yang ditetapkan. Kesultanana Surakarta, misalnya diatur Ellaui Lange Contract sedangkan kerajaan goa di Sulawesi selatan di atur dengan Kortre Verkalring.

Dengan demikian dalam masa pemerintah kolonial, warga masyarakat berhadapan dengan dua administrasi pemerintahan yaitu yang pertama pemerintah kolonial yang dipimpin oleh gubenur jenderal yang merupakan wakil dari pemerintahan Kerajaan Belanda. Di bawah gubernur jenderal ada sejumlah residen yang menjalani roda pemerintah provinsi, kemudian terdapat pula Controlier dan Assistant Controlier. Administasi pemerintahan asli ada dibawah pemertintahan kerajaan yang membawahi sejumlah bupati yang kemudian terdapat sejumlah Wedana dan Asisstent Wedana. Untuk lebih jelasnya dapat dilihat dalam diagram beikut ini:

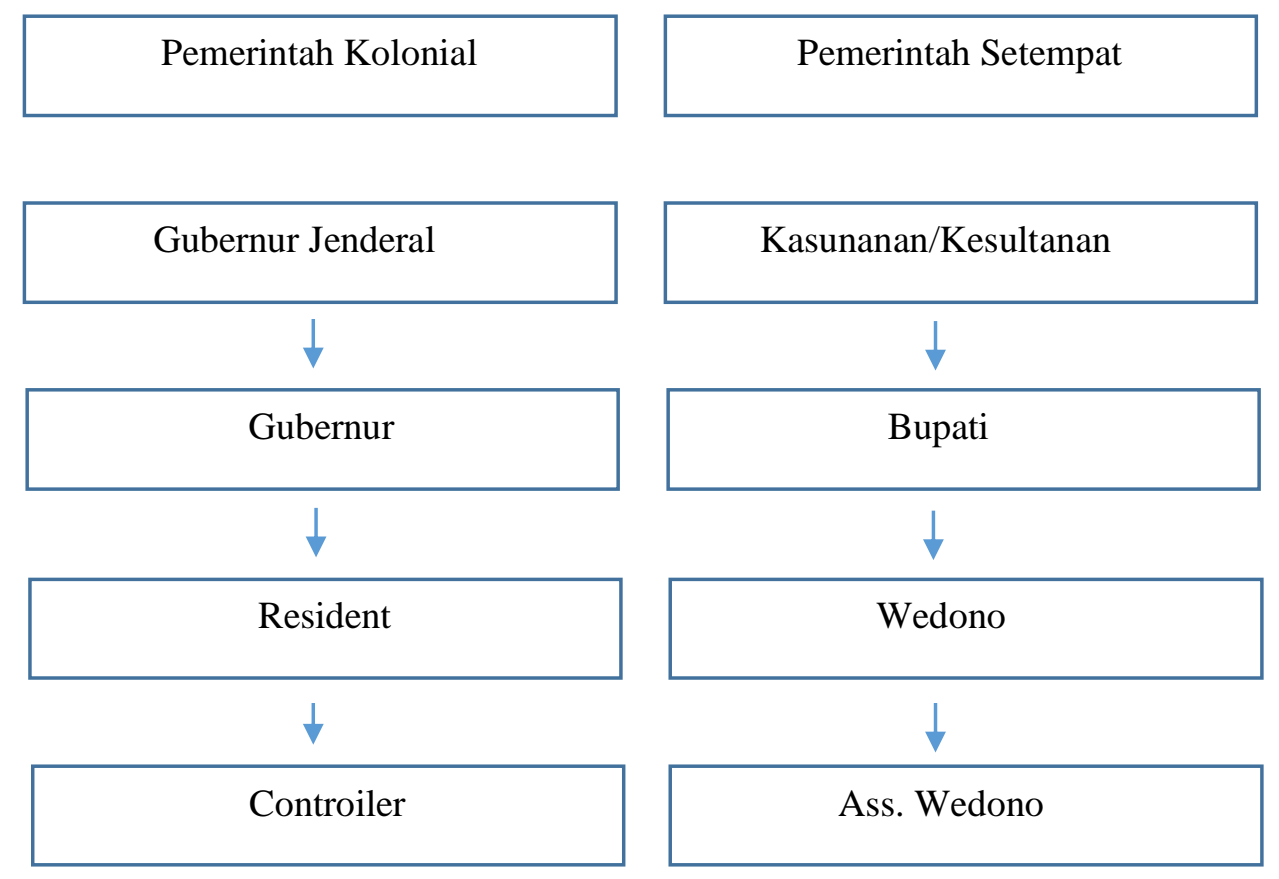

Sumber: Syaukani, Gaffar, Rasyid, 2012

Satu hal yang paling menonjol yang merupakan warisan dari pemerintahan kolonial adalah kecenderungan sentraliasi kekuasaan pada pusat pemerintahan, dan pola penyelengaraan pemerintahan daerah yang bertingkat. Hal ini masih sangat kuat dipraktekkan dalam penyelenggaraan pemerintahan di Indonesia dari waktu ke waktu. Perang dunia ke II kemudian menjalar ke Asia Timur. Jepang yang merupakan kekuatan militer yang sangat kuat melakukan invansi ke seluruh Asia Timur mulai dari Korea di Utara terus ke Daratan Cina, sampai ke Pulau Jawa dan sumatera. Pemerintahan kolonial Inggris di Birma, dan Malaya kemudian ditaklukan, demikian juga Amerika Serikat di Philiphina, serta Belanda di 
daerah Hindia Belanda (Jawa Sumatera Kalimatan, Sulawesi, Sunda Kecil, Maluku, dan Irian Barat. Pemerintahan bala tentara jepang yang singkat, sekitar tiga setengah tahun (1941-1945) ternyata melakukan perubahan perubahan yang cukup fundamental dalam pemerintahan daerah di bekas Hindia Belanda. Hindia Belanda kemudian dibagi ke dalam tiga wilayah kekuasaan militer, yaitu Sumatera yang berkedudukan di Bukit Tinggi dikuasai oleh kekuasaan militer Angkatan Darat, demikian juga di Jawa dan Madura yang berkedudukan di Jakarta, dan wilayah timur seperti sulawesi, Kalimantan, sunda kecil, dan Maluku diserahkan kepada Angkatan Laut.

Pihak penguasa militer di Jawa (Gunsireikan) mengeluarkan Undang-undang (Osamu Seirei) No. 27n tahun 1942 yang mengatur penyelengaaraan Pemerintahan Daerah. Dalam Osamu Seirei tersebut Jawa dibagi ke dalam beberapa Syuu, Kemudian Syuu dibagi lagi ke dalam beberapa Ken, dan Ken terbagi lagi ke dalam Si. Sedangkan daerah yang berkedudukan khusus disebut Tokubetu Si yang berkedudukan khusus disebut Tokubetu Si yang kedudukannya setingkat Syuu. Dan untuk pertama kalinya Provinsi tidak lagi masuk dalam strata pemerintahan daerah di jawa. Yang menjadi kepala daerah Syuu adalah Syuutyookan, sementara itu Tokubetu Si. Yang memimpin sebuah Ken adalah Kentyoo, demikian juga dengan Si dipimpin oleh Sityoo. Perlu juga ditambahkan bahwa kalau pada masa pemerintahan kolonial belanda di daerah ada namanya Raad, oleh pemerintahan bala tentara jepang dihapuskan, pemerintahan daerah sepenuhnya ada di bawah Kentyoo dan Sityoo yang dapat dikatakan memiliki kekuasaan tunggal (The Lieng Gie, 1993).

Sama halnya pada masa pemerintahan kolonial belanda, pemerintah daerah hampir sama sekali tidak memiliki kewenangan. Penyebutan "daerah otonom" bagi pemeritahan di daerah pada masa tersebut merupakan sesuatu yang bersifat misleading atau menyesatkan. Bahkan dalam kenyataannya, administrasi pemerintahan penjajahan jepang melakukan penetrasi ke dalam kehidupan masyakarat lebih jauh intesif dibandingkan dengan pemerintahan kolonial belanda. Karena kebutuhan mobilisasi sosial guna mendukung kegiatan peperangan, pemerintah bala tentara jepang di Asia, khususnya d Hindia Belanda, secara hirarkis sampai pada satuan masyarakat yang terendah. Karena keterbatasan personil pemerintahah jepang sangat bergantung kepada para "pangrehpraja" dalam rangka memobilisasi dukungan guna kepentingan peperangan. Pada pangprehraja tersebut memiliki kekuasaan yang sangat besar, akan tetapi di bawah control sepenuhnya dari kalangan penguasa militer jepang. Shigeru Sato (1994) mengungkapkan sebagai berikut:

"Thus a single pyramidal structure was created consisting of administrator with greatly enhanced powers but without sufficient experience or expertise, and without advisory bodies or the dual supervisory system. In the new system the pangprehraja had to assume all the actual administrastive functions and responsibility below the regency level under the strict, but not close, supervision of the japanesse residents (1994)".

Di era kemerdekaan, Pasal 18 UUD 1945 (redaksi lama) beserta penjelasannya menyatakan bahwa daerah Indonesia terbagi dalam daerah yang bersifat otonom atau bersifat daerah administrasi. UUD 1945 
yang disahkan Panitia Persiapan Kemerdekaan Indonesia (PPKI) pada tanggal 18 Agustus 1945, Pasal 18 yang bertajuk Pemerintahan Daerah itu selengkapnya berbunyi:

"Pembagian daerah Indonesia atas daerah besar dan kecil, dengan bentuk susunan pemerintahannya ditetapkan dengan undang-undang, dengan memandang dan mengingat dasar permusyawaratan dalam sistem pemerintahan negara, dan hak asal-usul dalam daerah-daerah yang sifatnya istimewa".

Ketua PPKI Ir. Soekarno dalam pengantarnya berkenaan dengan pasal pemerintahan daerah itu, berkata : 'Tentang Pemerintah Daerah, di sini hanya ada satu pasal, yang berbunyi: "Pemerintah Daerah disusun dalam Undang-Undang“.

Hanya saja, dasar-dasar yang telah dipakai untuk negara itu juga harus dipakai untuk Pemerintah Daerah. Artinya, Pemerintah Daerah harus juga bersifat permusyawaratan, dengan kata lain harus ada Dewan Perwakilan Daerah. Dan adanya daerah-daerah istimewa diindahkan dan dihormati, Kooti-Kooti, Sultanat-Sultanat tetap ada dan dihormati susunannya yang asli, akan tetapi itu keadaannya sebagai daerah, bukan negara; jangan sampai ada salah paham dalam menghormati adanya daerah "Zelfbesturende landschappen", hanyalah daerah saja, tetapi daerah istimewa yaitu yang mempunyai sifat istimewa. Jadi daerah-daerah istimewa itu suatu bagian dari Staat Indonesia, tetapi mempunyai sifat istimewa, mempunyai susunan asli. Begitupun adanya "Zelfstandige Gemeenschappen" seperti desa, di Sumatera negeri (di Minangkabau), marga (di Palembang), yang dalam bahasa Belanda disebut "Inheemsche Rechtsgemeenschappen". Susunannya asli itu dihormati”.

Di kala itu, yang disahkan PPKI adalah Pembukaan UUD 1945, Batang Tubuh (37 pasal), Aturan Peralihan (4 pasal), dan Aturan Tambahan (2 butir angka), dan belum ada Penjelasan. Penjelasan, yang kelak dikenal dengan penamaan Penjelasan UUD 1945, baru dimunculkan kurang lebih enam bulan kemudian, dimuat dalam Berita Repoeblik Indonesia Tahun II Nomor 7, tanggal 15 Februari 1946, disertai pengantar redaksi, sebagai berikut:

"Oentoek memberikan kesempatan lebih loeas lagi kepada oemoem mengenai isi OendangOendang Dasar Pemerintah jang semoelanya, di bawah ini kita sadjikan pendjelasan selengkapnja”.

Penjelasan tersebut memang tidak dimaksudkan sebagai bagian naskah otentik konstitusi, apalagi penjelasan itu tidak dibuat serta tidak disahkan oleh PPKI. Pemuatan Penjelasan UUD 1945 pada halaman 51 sampai dengan 56 Berita Repoeblik Indonesia terpisah dari pemuatan UUD 1945 (halaman 45 sampai dengan 48), diantarai dengan pemuatan nama-nama daerah (provinsi) dalam lingkungan republik serta Makloemat Pemerintah Repoeblik Indonesia, bertanggal 1 November 1945, yang ditandatangani Wakil Presiden Drs. Mohamad Hatta. Menelaah rumusan bagian 'Oemoem' dari Penjelasan UUD 1945 serta 
Penjelasan tafsir setiap pasal UUD dapat disimpulkan bahwasanya naskah Penjelasan UUD 1945 hampir seluruhnya disusun oleh Prof. Mr. Dr. Soepomo, Menteri Kehakiman di awal Pemerintahan RI.

Pada Penjelasan Pasal 18 UUD 1945 mengenai Pemerintahan Daerah, dikemukakan:

- Oleh karena Negara Indonesia itu suatu eenheidsstaat, maka Indonesia tak akan mempunyai daerah di dalam lingkungannya yang bersifat staat juga. Daerah Indonesia akan dibagi dalam daerah propinsi dan daerah propinsi akan dibagi pula dalam daerah yang lebih kecil. Di daerah-daerah yang bersifat otonom (streek dan locale rechtgemeenschappen) atau bersifat daerah administrasi belaka, semuanya menurut aturan yang akan ditetapkan dengan undang-undang. Di daerah-daerah yang bersifat otonom akan diadakan badan perwakilan daerah, oleh karena di daerah pun pemerintahan akan bersendi atas dasar permusyawaratan.

- Dalam teritori Negara Indonesia terdapat lebih kurang 250 zelfbesturende landschappen dan volksgemeen-schappen, seperti desa di Jawa dan Bali, negeri di Minangkabau, dusun dan marga di Palembang dan sebagainya. Daerah-daerah itu mempunyai susunan asli, dan oleh karenanya dapat dianggap sebagai daerah yang bersifat istimewa.

Pada 1948 dikeluarkan UU No. 22 tahun 1948 guna menyempurnakan UU sebelumnya yang dirasakan masih dualistic. UU No. 22 tahun 1948 ini menganut asas otonomi formal dan kepmateriil sekaligus. Ini terlihat dari pasal 23 (2) yang menyebut urusan yang diserahkan kepada Daerah (materil) dan pasal 28 yang mnyebutkn adanya pembatasan-pembatasan bagi DPRD untuk tak membuat Perda tertentu yang telah diatur oleh pemerintah yang tingkatanya lebih tinggi. Hal ini yang menunjukan adanya keinginan untuk memperluas otonomi daerah.

Permasalahan pemerintahan di era Orde Lama, kurang mampu diredam Orde Baru. Orde Baru hanya menyelesaikan permasalahan terkait pengorganisasian militer, namun pada saat yang sama justru semakin memperparah dua permasalahan terpenting yaitu mengembangkan sistem pemerintahan dan keuangan daerah yang semakin tersentralisir, dan semakin memperlebar dikotomi struktur ekonomi yang fundamental antara Jawa dan Luar Jawa. Sentralisasi sumberdaya politik dan ekonomi di tangan sekelompok kecil elit di pemerintah pusat adalah konsekuensi yang melekat dari sistem politik otoritarian tersebut. Bahkan, sentralisasi ini masih diperparah lagi dengan dikembangkannya uniformitas supra- dan infra-struktur politik.

Orde Baru mengatur pemerintahan lokal secara detail dan diseragamkan secara nasional. Organorgan supra-struktur politik lokal diatur secara terpusat dan seragam tanpa mengindahkan heterogenitas 'sistem politik' lokal yang telah eksis jauh sebelum terbentuknya konsep kebangsaan Indonesia. Melalui 
strategi korporatisme negara, pemerintah Orde Baru melakukan penunggalan kelompok kepentingan yang dikontrol secara terpusat. Para buruh di seluruh nusantara hanya diakui eksistensinya apabila bernaung di bawah SPSI. Demikian pula halnya untuk pegawai negeri yang telah disediakan Korpri, untuk guru telah disediakan PGRI, untuk petani telah disediakan HKTI, untuk pengusaha telah disediakan KADIN, untuk para wartawan telah disediakan PWI, dan lain-lain. Kondisi tersebut diperparah dengan adanya sentralisasi kelembagaan kelompok kepentingan dan kemudian menjadi salah satu mesin politik untuk membangun dukungan masyarakat (walaupun mungkin semu) kepada pemerintah melalui organisasi payung yang dinamakan Golongan Karya.

Dengan kata lain, dalam era Orde Baru telah terjadi proses negaraisasi (state formation) secara luar biasa yang berusaha menisbikan eksistensi politik lokal yang telah lama berakar di masyarakat. Hal ini menjadi semakin efektif melalui keterlibatan militer dalam day-to-day politics yang secara intens menumbuhkan suasana ketakutan (baik represi ideologis maupun fisik) di kalangan komunitas politik yang berusaha menolak dominasi pusat. Administrasi negara juga terlalu banyak merambah di dalam kehidupan privat, seperti pengurusan Kartu Tanda Penduduk, Surat Kelakuan Baik, Keterangan Bersih Lingkungan, dan lain-lain yang menciptakan ketergantungan individu kepada negara.

Mekanisme kontrol politik secara nasional tersebut bahu-membahu dengan sentralisasi pengelolaan sumber daya ekonomi secara nasional yang sangat bias pusat (Jakarta, dan kemudian Jawa). Dengan wacana pembangunan nasional, pemerataan pembangunan antar daerah dan integrasi nasional, pemerintah melakukan pengelolaan sumber daya ekonomi daerah secara nasional. Pertambangan, hutan, beberapa hasil laut dan beberapa jenis perkebenan dikelola secara nasional yang hasilnya dibawa secara penuh ke Jakarta.

Mekanisme sentralistis semacam ini terus berkepanjangan karena dua hal utama. Pertama, pada tingkat nasional, elit politik pembuat keputusan tidak mempunyai basis politik lokal sama sekali. Kekuatan eksekutif nasional (yang bisa jadi hanya Lembaga Kepresidenan, dan bahkan hanya Suharto saja) yang menjadi aktor tunggal dalam pentas politik nasional tidak berakar dari bawah, dan bahkan tidak membutuhkan dukungan politik dari masyarakat untuk kelangsungan kekuasaan politik mereka. Kedua, pada tingkat daerah, masyarakat politik lokal teralienasi dari mekanisme politik yang telah sepenuhnya ternasionalisasi. Bahkan juga, arena politik lokal telah dimonopoli oleh orang pusat yang ada di daerah.

Karena supra-struktur dan infra-struktur politik lokal telah mengalami negaraisasi secara substansial, maka praktis tidak ada resistensi politik daerah yang memadai terhadap sentralisasi pengelolaan sumber daya ekonomi yang terpusat ini. Dengan kata lain, secara ringkas bisa dikatakan bahwa berbagai sosok bias pusat dalam distribusi sumber daya politik dan ekonomi yang terjadi selama 32 tahun terakhir ini adalah produk dari sebuah rejim politik otoritarian yang membangun legitimasi politiknya melalui sentralisasi serta monopoli sumber daya politik dan ekonomi secara nasional. 
Namun, cara kerja politik yang sentralistis dan monolitis ini hanya mampu memperbaiki keadaan sesaat dan bersifat semu belaka. Sinyal-sinyal kegagalan pengaturan politik lokal Orde baru semakin mencolok ke permukaan tatkala beberapa masyarakat daerah, terutama Irian Jaya dan Aceh, menuntut perubahan mendasar dalam pengaturan politik lokal dan dalam hubungan pusat-daerah di tahun 1997an. Bahkan, salah satu bentuk tuntutan itu adalah tuntutan separatis untuk membentuk negara sendiri. Tuntutan pembentukan negara sendiri atau melepaskan diri dari bagian wilayah NKRI benar-benar terwujud yakni dengan lepasnya Propinsi Timor Timur dari bagian wilayah NKRI melalui referendum pada era Presiden Habibie.

Fakta-fakta tentang adanya tuntutan separatis yang akhirnya diwujudkan melalui lepasnya Timor Timur dari wilayah Indonesia merupakan bukti bahwa 'ketaatan' komunitas politik lokal terhadap pusat yang terjadi selama ini adalah sebuah ketaatan yang semu dan penuh keterpaksaan. Tentu saja konsep negara-bangsa semacam ini sangat rentan terhadap gejolak. Tatkala krisis ekonomi melanda Indonesia, tatkala reformasi politik digulirkan masyarakat, dan tatkala pelanggaran HAM di Indonesia semakin menjadi sorotan dunia, maka tatkala itulah proses pembusukan politik (bukan pembangunan politik) Orde Baru mulai terangkat ke permukaan.

Akhirnya, desentralisasi atau otonomi daerah pada masa Orde Baru bukannya tak ada sama sekali. Undang-undang No 5 tahun1974 tentang Pokok-pokok Pemerintahan di Daerah. Namun, sebagaimana terwujud dalam praktiknya, UU tersebut tampaknya lebih disusun dalam kerangka sentralisasi ketimbang merupakan sebuah landasan bagi terlaksananya desentralisasi. Salah satu penjelasan UU tersebut juga secara tegas mengatakan otonomi daerah pada hakekatnya lebih merupakan kewajiban daripada hak, yaitu kewajiban daerah untuk ikut melancarkan jalannya pembangunan.

Pada Era Reformasi, kebijakan desentralisasi bermula dari Ketetapan MPR-RI Nomor XV/MPR/1998 tentang Penyelenggaraan Otonomi Daerah; Pengaturan, Pembagian, dan Pemanfaatan Sumber Daya Nasional yang Berkeadilan; serta Perimbangan Keuangan Pusat dan Daerah Dalam Kerangka Negara Kesatuan Republik Indonesia. Dilanjutkan dengan 7 Mei 1999, lahir UU No. 22/1999 tentang Pemerintahan Daerah selanjutnya UU No. 25/1999 yang mengatur hubungan keuangan pusat dan daerah, menggantikan UU No. 5/1974 yang sentralistik.

Kedua undang-undang ini mengatur wewenang otonomi yang diberikan luas kepada pemerintah tingkat kabupaten dan kota. Bupati dan walikota pun dinyatakan bukan lagi sebagai aparat pemerintah yang hierarkis di bawah gubernur. Jabatan tertinggi di kabupaten dan kota itu merupakan satu-satunya kepala daerah di tingkat lokal, tanpa bergantung pada gubernur. Setiap bupati dan walikota memiliki kewenangan penuh untuk mengelola daerah kekuasaannya. Keleluasaan atas kekuasaan yang diberikan kepada bupati/walikota dibarengi dengan mekanisme kontrol (checks and balances) yang memadai antara eksekutif 
Parlemen di daerah tumbuh menjadi sebuah kekuatan politik riil yang baru. Lembaga legislatif ini secara merdeka dapat melakukan sendiri pemilihan gubernur dan bupati/walikota tanpa intervensi kepentingan dan pengaruh politik pemerintah pusat. Kebijakan di daerah juga dapat ditentukan sendiri di tingkat daerah atas kesepakatan pemerintah daerah dan dewan perwakilan rakyat daerah (DPRD). Undangundang yang baru juga mengatur bahwa setiap peraturan daerah dapat langsung dinyatakan berlaku setelah disepakati sejauh tidak bertentangan dengan peraturan perundangan yang lebih tinggi tingkatannya. Hal ini kontras berbeda dengan ketentuan sebelumnya yang mensyaratkan adanya persetujuan dari penguasa pemerintahan yang lebih tinggi bagi setiap perda yang akan diberlakukan.

UU No 22/1999 dan UU No 25/1999 juga memberikan kerangka yang cukup ideal bagi terwujudnya keadaan politik lokal yang dinamis dan demokratis di setiap daerah. Namun, praktik-praktik politik yang menyusul setelah itu masih belum sepenuhnya memperlihatkan adanya otonomi yang demokratis. Setidaknya terdapat dua penyebab utama mengapa hal ini bisa terjadi.

Pertama, pemerintah pusat rupanya tak kunjung serius memberikan hak otonomi kepada pemerintahan di daerah. Ketidakseriusannya dapat dilihat dari pembiaran pemerintah pusat terhadap berbagai peraturan perundang-undangan lama yang tidak lagi sesuai dengan UU otonomi yang baru. Padahal, ada ratusan Peraturan Pemerintah, Keputusan Presiden dan berbagai peraturan lainnya yang harus disesuaikan dengan kerangka otonomi daerah yang baru. Ketiadaan aturan pelaksanaan baru yang mendukung otonomi daerah yang demokratis menjadikan kedua UU menyangkut otonomi daerah itu mandul dan tak efektif. Sementara di tingkat daerah, ketiadaannya telah melahirkan kebingungan.

Kedua, desentralisasi telah menggelembungkan semangat yang tak terkendali di kalangan sebagian elit di daerah sehingga memunculkan sentimen kedaerahan yang amat kuat. Istilah "putra daerah" mengemuka di mana-mana mewakili sentimen kedaerahan yang terwujud melalui semacam keharusan bahwa kursi puncak pemerintahan di daerah haruslah diduduki oleh tokoh-tokoh asli dari daerah bersangkutan. Hal ini tentu saja bukan sesuatu yang diinginkan apalagi menjadi tujuan pelaksanaan otonomi daerah. Bagaimanapun, fenomena "putra daerah" itu begitu meruak di berbagai daerah.

Hubungan pusat dan daerah juga masih menyimpan ancaman sekaligus harapan. Menjadi sebuah ancaman karena berbagai tuntutan yang mengarah kepada disintegrasi bangsa semakin besar. Bermula dari kemerdekaan Timor Timur (atau Timor Leste) pada tanggal 30 Agustus 1999 melalui referendum. Berbagai gelombang tuntutan disintegrasi juga terjadi di beberapa daerah seperti di Aceh, Papua, Riau dan Kalimantan. Meskipun ada sejumlah kalangan yang menganggap bahwa kemerdekaan Timor Timur sudah seharusnya diberikan karena perbedaan sejarah dengan bangsa Indonesia dan merupakan aneksasi rezim Orde Baru, tetapi efek domino yang timbulkannya masih sangat dirasakan, bahkan dalam MoU Helsinki 
yang menghasilkan UU Pemerintahan Aceh. Gejolak terus berlanjut hingga, Aceh dan Papua akhirnya diberi otonomi khusus.

Menjadi harapan, karena Amandemen kedua konstitusi, telah mengubah wajah Pemerintahan Daerah menjadi lebih demokratis dan lebih bertanggung jawab. Pasal 18 ayat (5) UUD 1945 (redaksi baru), Perubahan Kedua, berbunyi, "Pemerintahan Daerah menjalankan otonomi seluas-luasnya, kecuali urusan pemreintahan yang oleh undang-undang ditentukan sebagai urusan Pemerintah Pusat". Pasal 1 ayat (1) UUD 1945 tidak dapat dibaca secara terpisah dengan Pasal 18 ayat (1) dan (5) UUD 1945 (redaksi baru).

Dalam pemahaman ini, M. Laica Marzuki (2007) mengatakan, bentuk negara (de staatsvorm) RI secara utuh harus dibaca -dan dipahami- dalam makna: Negara Indonesia ialah Negara Kesatuan yang berbentuk Republik, yang disusun berdasarkan desentralisatie, dijalankan atas dasar otonomi yang seluasluasnya, menurut Pasal 1 ayat (1) UUD 1945 (redaksi baru) juncto Pasal 18 ayat (1) dan (5) UUD 1945 (redaksi baru).

Lima tahun berlangsung, UU No. 22/1999 dan UU No. 25/1999 dipandang perlu direvisi, hingga lahirlah UU No. 32/2004 tentang Pemerintahan Daerah dan UU No. 33/2004 tentang Perimbangan Keuangan menggantikan UU No. 22/1999 dan UU No. 25/1999 tersebut. Pasal 1 angka 7 UU Nomor 32 Tahun 2004 tentang Pemerintahan Daerah merumuskan desentralisasi adalah penyerahan wewenang pemerintahan oleh pemerintah kepada daerah otonom untuk mengatur dan mengurus pemerintahan dalam sistem Negara Kesatuan Republik Indonesia. Pemerintah sebagaimana dimaksud dalam pasal tersebut adalah Pemerintah Pusat, dalam hal ini Presiden RI yang memegang kekuasaan pemerintahan negara RI, menurut UUD 1945 (Pasal 1 angka 1 UU Nomor 32 Tahun 2004).

Penyerahan wewenang pemerintahan oleh pemerintah pusat kepada daerah otonom bermakna peralihan kewenangan secara delegasi, lazim disebut delegation of authority. Tatkala terjadi penyerahan wewenang secara delegasi, pemberi delegasi kehilangan kewenangan itu, semua beralih kepada penerima delegasi. Dalam hal pelimpahan wewenang secara mandatum, pemberi mandat atau mandator tidak kehilangan kewenangan dimaksud. Mandataris bertindak untuk dan atas nama mandator.

Dengan demikian, dalam hal penyerahan kewenangan pemerintahan oleh pemerintah pusat kepada daerah otonom secara delegasi, untuk mengatur dan mengurus urusan pemerintahan memberikan konsekuensi bahwasanya pemerintah pusat kehilangan kewenangan dimaksud. Semua beralih kepada daerah otonom, artinya menjadi tanggungjawab pemerintahan daerah, kecuali urusan pemerintahan yang oleh undang-undang dinyatakan sebagai urusan pemerintah pusat. Pasal 10 ayat (3) Undang-Undang Nomor 32 Tahun 2004 menetapkan, bahwasanya urusan pemerintahan yang menjadi urusan pemerintah pusat meliputi a. politik luar negeri, b. pertahanan, c. keamanan, d. yustisi, e. moneter dan fiskal, f. agama. Pusat tidak boleh mengurangi, apalagi menegasikan kewenangan pemerintahan yang telah diserahkan kepada daerah otonom. Namun demikian, daerah otonom-daerah otonom tidak boleh melepaskan diri dari Negara 
Kesatuan RI. Betapa pun luasnya cakupan otonomi, desentralisasi yang mengemban pemerintahan daerah tidaklah boleh meretak-retakkan bingkai Negara Kesatuan RI.

Secara formal normatif, arah desentralisasi sudah cukup baik. Namun, dalam tataran empiris komitmen pemerintah pusat tidak konsisten. Praktek-praktek monopoli dan penguasaan urusan-urusan strategis yang menyangkut pemanfaatan sumber daya alam termasuk perizinan di daerah, dikuasai pusat.

Intervensi pusat pada daerah begitu besar. Penyerahan urusan/wewenangan yang semestinya dilakukan dengan penyerahaan sumber keuangan tidak dilakukan. Pusat melakukan penganggaran pembangunan daerah tanpa melibatkan DPRD sebagai unsur penyelenggara pemerintahan daerah. Pembiayaan fungsi-fungsi pemerintahan di daerah lebih dominan berasal dari APBN, yang semestinya diserahkan sebagai dana perimbangan untuk APBD. UU No. 32 Tahun 2004 ini sempat mengalami perubahan berdasarkan UU No. 8 tahun 2005 dan UU No. 12 tahun 2008.

Tahun 2007, kemudian dikeluarkan PP No. 38 tahun 2007 tentang pembagian urusan. Walau telah dibagi-bagi kewenangan pusat dan daerah, namun PP ini dipandang telah mendelegasikan kewenangan daerah. Revisi lebih komprehensif kemudian diwacanakan kembali pada UU No. 32/2004 untuk lebih menterjemahkan lebih kongkrit kewenangan pusat dan daerah.

Uraian seingkat yang diungkapkan dalam bagian ini dapat mengambarkan bahwa perjalanan kebijakan desentralisasi yang telah dirintis semenjak Negara ini merdeka pada tahun 1945. Tentu saja tidak mungkin perjalan kebijaksanaan yang dimulai dengan UU Nomor 1 tahun 1945 yang kemudian disempurnakan, diubah, diganti, dan dengan berbagai UU no. 22 tahun 1948, UU nomor 1 tahun 1957, penetapan presiden No. 6 tahun 1959 yang disempurnakan, dan kemudian UU No. 18 tahun 1965, diuraikan dengan selengkap mungkin karena berhadapan dengan keterbatasan yang ada.

Akan tetapi, satu hal yang perlu mendapatkan perhatian dan menjadi pelajaran bagi bangsa Indonesia adalah bahwa perubahan kebijakan pemerintahan daerah sanagt ditentukan oleh konfigurasi politik nasional yang berkembang dari waktu ke waktu. Kalau politik ditingkat Jakarta mengalami perkembangan yang dinamis dan menunjukkan ke arah demokrasi.

\section{B. LITERATUR REVIEW}

\section{Desentralisasi Dan Media Lokal}

Tidak ada yang menafikan kenyataan seperti yang kita hadapi sekarang ini bahwa agenda Otonomi Daerah merupakan sebuah agenda nasional yang sangat penting dan telah menjadi agenda public yang utama ditengah-tengah menghadapi persoalan bangsa yang semakin kompleks dan tidak jelas arahnya. Sejak diberlakukannya kedua Undang-Undang tentang Pemerintahan Daerah yaitu Undang-Undang No. 22 tahun 1999 dan Undang-Undang Nomor 24 tahun 1999, dapat dinyatakan bahwa hampir tiada hari yang 
kita lewati tanpa membicarakan masalah desentralisasi dan otonomi daerah. Masalah ini tidak kalah populernya dengan sejumlah persoalan bangsa yang sedang kita hadapi saat ini.

Desentralisasi/otonomi daerah diharapkan dapat menjadi salah satu pilihan kebijaksanaan nasional yang dapat mencegah kemungkinan terjadinya disintegrasi nasional. Kita tidak dapat menutup mata terhadap persoalan yang dihadapi Bangsa dan Negara sekarang ini dalam menyelesaikan masalah Aceh dan Irian Jaya. Otonomi merupakan salah satu opsi kebijkasanaan yang tepat untuk tetap menjaga kedua wilayah Negara tersebut tetap dalam kerangka Negara Kesatuan, disamping peningkatan derajat keadilan social serta sejumlah kebijaksanaan ekonomi secara khusus yang akan diberlakukan kepada kedua daerah itu. Konsekuensinya adalah bahwa dengan penerapan otonomi daerah tersebut membuka keran daerah untuk memajukan daerahnya sendiri dengan mengatasnamakan wacana pemekaran daerah. Tak heran mengapa momen penerapan undang-undang otonomi daerah itu pantas disebut dengan cerdas dimanfaatkan berbagai pihak untuk mendorong pemekaran daerah yang kini jumlah frekuensinya mendekati 200 kasus pemekaran. Pemekaran daerah menjadi fenomena khas pasca reformasi. Bayangkan saja, dalam kurun waktu lima tahun sejak 1999, Indonesia telah menambang jumlah baru. Ini membuat jumlah provinsi indoensia kini berkutat pada angka 33. Sejak tahun 2006 saja Departemen dalam negeri menerima puluhan usulan pemekaran Provinsi, salah satunya adalah usulan pemekaran Aceh yang dibagi menjadi tiga provinsi yaitu Usulan Provinsi Samudera Pasai Raya, Aceh Barat Selatan, dan Aceh Leuser Antara.

Usulan-usulan pemekaran provinsi itu sebagian besar pada posisi sedang diproses pemerintah pusat kini. Di samping itu, pun banyak aspirasi pemekaran provinsi yang baru pada tahap deklarasi di daerah, atau diwacanakan panitia atau komite pembentukan lewat media local dan nasional. Misalnya di Sulawesi Utara yang santer diserukan aspirasi membentuk provinsi Minahasa Raya, Provinsi Totabuan di wilayah Bolang Mongondow dan Provinsi Provinsi Kepulauan Nusa Utara di perbatasan Indonesia-Philippina.

Dalam penelitian ini, penulis ingin mengarisbawahi bahwa penelitian ini tidak berfokus pada dinamika pemekaran daerah ini bisa terjadi yang lebih kepada konsteks politik, tapi penulis ingin melihat sisi lain tentang bagaimana wacana/ide pemekaran wilayah ini muncul dihadapan masyarakat. Dengan demikian, media sebagai salah satu medium dalam mewartawakan wacana ini kemudian menarik untuk dilirik. Inilah yang ingin dilihat oleh peneliti. Pada konteks ini, media local menjadi pilihan yang utama sebagai objek penelitian ketimbang dengan media nasional. Kedekatan media local dengan masyarakat local yang membuat masyarakat local lebih memilih mendapatkan informasi dari media local itu sendiri khususnya terkait dengan isu pemekaran wilayah. Dengan kekuatan konstruksi yang dimiliki oleh media, khususnya media local, masyarakat diharapkan mendapatkan pilihan yang matang dan rasional. Lalu, pertanyaan kemudian adalah bagaimana media mengkonstruksi isu pemekaran itu? Konstruksi macam apa yang dilakukan media? apakah media dalam mengkonstruksi sebuah isu tersebut menonjolkan suatu hal atau jangan-jangan menghilangkan suatu hal lainnya? 
Pertanyaan semacam itu, idelanya dapat dijawab dengan pendekatan bagaimana teks itu dibentuk. Untuk mengetahui pembentukan teks itu sendiri, analisis framing dirasakan cocok untuk dilakukan. Namun, sebelum melangkah jauh untuk mengetahui bagaimana teks dikonstruksi, perlu untuk melihat bagaimana peran media local dalam menghadapi persoalan-persoalan daerah, berperan negative atau positif?

\section{Media Lokal dan Isu lokal}

Seperti yang diungkapkan di atas, bahwa gelombang desentralisasi pasca 1998 paling tidak telah menelurkan dua konsekuensi. Pertama, otonomi daerah yang dapat memberikan kesempatan daerah-daerah untuk memekarakan wilayahnya yang awalnya tersentralistik. Kedua, konsekuensinya adalah berkembangnya pers yang lebih bebas (Yusuf, 2011). Kedua hal tersebut pada dasarnya tidak bisa dipisahkan secara parsial, karena hubungan kedua hal tersebut cukup erat. Walapun demikian untuk menjelaskan hubungan kedua hal tersebut perlu dipilah satu persatu kemudian baru digabungkan kembali.

Pada konteks Indonesia, media muncul bak jamur di musim hujan pasca reformasi. Pada masa orde baru, media tidak dapat berkembang sabanyak ini. Semasa orde baru, melalui UU nomor 11 tahun 1966, pemerintah melakukan control terhadap pers. Undang-Undang tersebut berisikan mengenai ketentuanketantuan pokok pers perihal Surat Izin Terbit (SIT) dari Departemen Penerangan dan Surat Izin Cetak (SIC) dari Komando Pemulihan Keamanan Dan Ketertiban (Koptamtib). Tanpa kedua izin tersebut, terbitan pers dianggap illegal. Selain itu, ketika izin tersebut dicabut, otomatis terbitan tersebut juga diberangus. Lima belas tahun setelah SIT dan SIC diundangkan pada tahun 1982 aturan tersebut diganti menjadi Surat Izin Usaha Penerbitan Pers (SIUUP) oleh Departemen Penerangan. Fungsinya tetap sama, hanya penyebutannya yang berbeda.

Perkembangan demokrasi ditingkat local serta densentralisasi di era post soeharto dinilai memberi angin optimist sekaigus pesimistik oleh beberapa kalangan (Erb Sulistyanto, Faucher, 2002; Aspinal dan Fealy, 2003; Turner et al, 2003). Pandangan yang optimistis beragumen bahwa seluruh kekuatan atau pihakpihak yang ditekan di orde baru akan bersatu mebantu negeri dengan melibatkan semua pihak termasuk masyarakat. Selain itu, dengan pola pemerintahan yang teredesentrasliasi, digarapkan isu-isu kebijakan lokal bisa lebih mudah dan cepat untuk ditangani.

Setelah orde baru dilengserkan, SIUUP pun dicabut. Kemudian digantikan oleh Undang-undang Pers no. 40 tahun 1999. Dalam undang-undang yang baru ini, cukup mengantongi Surat Izin Usaha Perdagangan (SIUP) pun sudah cukup untuk mendirikan usaha penerbitan pers. Jika mempunyai modal, semua orang dapat mendirikan usaha penerbitan pers. Pun demikian kemajuan teknologi seperti internet bisa menjadikan setiap individu bak industri pers itu sendiri. Tak ayal jika pers menjamur dimanapun. Baik lingkup nasional maupun local. 
Jika penerbitan pers semakin banyak, berarti tentu juga semakin tinggi peningkatan kemungkinan terjadinya demokrasi yang berkualitas. Banyaknya penerbitan pers ini dapat menjadi apa yang dikatakan Dahl sebagai Sumber Informasi Alternatif. Dahl (1999) berpendapat bahwa adanya sumber informasi alternative adalah salah satu prasyarat dari demokrasi. Ketika sumber informasi hanya terpusat ataupun terkelompok sangat mungkin informasi hanya terkandung di dalamnya mengandung kepentingan pesan. Dengan banyaknya sumber informasi, meski tidak menutup kemungkinan untuk ditumpangi kepentingan tertentu, setidaknya masyarakat bisa tahu beragam informasi. Alhasil, untuk menenetukan sikapnya atau hanya untuk sekedar menilai situasi, mereka memperolehnya dengan pemikiran dan pertimbangan yang matang dan rasional.

Sebelum melihat jauh peranan media local dalam memberitakan isu-isu local, pendefinisian apa yang dimaksud dengan media local itu juga harus diperjelas di sini, karena pada dasarnya ada perbedaan dan perdebatan yang cukup menarik dalam melihat bagaimana yang dimaksud dnegan media local itu sendiri. Andreas, Yoseph Gual (2013) misalnya mengatakan bahwa terminologi media lokal biasanya dialamatkan kepada media yang penyebaran sirkulasinya hanya sebatas daerah tertentu dan berkedudukan di provinsi, kabupaten/kota atau wialayah-wilayah kecil. Indicator lainnya, masih menurut Andreas, adalah media local dapat dlihat melalui rubrikasi atau program acara atau isi media yang lebih banyak berhubungan dengan masalah atau peristiwa atau isu local.

Hal ini selaras dengan apa yang diutarakan Siregar ( ) Pemberitaan atau orientasi lokal, dalam pandangan Ashadi Siregar, merupakan salah satu ukuran untuk melihat apakah sebuah media bisa disebut media lokal atau tidak, di samping sirkulasi. Siregar membuat tiga "tingkatan" media berdasarkan orientasi dan sirkulasi tersebut, yang merupakan "tingkatan" keduanya: lokal, regional, dan nasional. Menurut Siregar, "nasional melingkupi seluruh wilayah negara; regional mencakup sebagian wilayah nasional, bersifat antar daerah; sedang lokal mencakup satu kota atau daerah terbatas." Bahkan lebih jauh lagi, Franklin memberikan definisi yang lebih ketat ketimbang Siregar. Bob Franklin bahkan mensyaratkan media lokal "dimiliki orang lokal, diproduksi secara lokal, mempekerjakan jurnalis lokal, melaporkan apa yang menjadi konsen lokal, dan dibaca oleh penduduk lokal. Kalau Siregar hanya menekankan orientasi pemberitaan dan wilayah edar, Franklin menambahkan pemilik, produksi, dan pekerja media mesti juga bersifat lokal.

Meskipun membuat definisi ketat, Franklin pesimis semua syarat lokal itu bisa dipenuhi. Franklin sendiri menyebutkan, di masa sekarang, apa yang disebut media lokal tinggal nama semata. Pemilik media lokal kerap kali adalah kelompok jaringan media yang tidak hanya memiliki media di suatu daerah tetapi juga di daerah lain, bahkan bisa jadi kelompok industri dari negara lain. Dengan kepemilikan yang demikian, produksi bisa berada di tempat yang jauh serta keputusan redaksional ditentukan dari wilayah 
lain. Hal yang paling mengkhawatirkan, sebagai konsekuensinya, adalah terputusnya relasi antara masyarakat suatu wilayah dan media yang beredar di sana.

Pada cakupan local, media lokal sangat berperan dalam menuntun rasionalisasi keputusan oleh masyarakat yang termasuk dalam lingkup wilayah media tersebut. Media local memiliki peran kebih penting daripada media nasional itu sendiri. Hal ini bisa dilihat dari cakupan dan proporsi pemberitaan yang diangkat adalah lebih banyak mengacu pada wilayah tersebut. Seperti yang diungkapkan Siregar (2002), media local memang ditujukan secara lebih spesifik kondisi psikografis dan geografis tertentu. Memang tidak menutup kemungkinan media nasional juga memberitakan peristiwa daerah. Hanya saja pasti proporsi serta perspektif yang digunakan akan berbeda. Penerimaan oleh warga masyarakatpun juga akan berbeda. Dengan berbekal Proximity yang dimiliki oleh media local, informasi yang diterima oleh masyarakat cenderung meningkat.

Selain itu, hal ini juga akan menjadi niche market untuk memperluas bidang usaha yang merupakan celah untuk meningkatkan kesadaran warga kondisi yang terjadi di daerah sendiri. Istilah lainnya menurut Schieck (2003), adalah mengedukasi warga terhadap isu-isu yang mempengaruhi kehidupan mereka. Selain itu, Munculnya media local juga merupakan buah hasil dari dinamika lokal seiring kebijakan desentralisasi (Siregar, 2007). Perubahan lanskap politik Indonesia yang menjadikan kabupaten dan kota sebagai basis otonomi pada gilirannya membutuhkan ruang publik bersama yang berfungsi menghasilkan imajinasi komunitas dan identitas yang dicita-citakan (Benedict, 1983) Dalam sejarah Indonesia modern, media dianggap mampu memenuhi tugas tersebut. Walhasil, meskipun merupakan institusi bisnis, media lokal sejatinya tidak melupakan tugasnya sebagai institusi sosial. Dua peran tersebut seyogianya berjalan beriringan.

\section{Media Lokal sebagai Pengawal Demokrasi?}

Desentralisasi menjadi salah satu fenomena penting yang harus disebut dalam era 10 tahun terakhir, dimana kekuasaan pemerintah pusat yang besar di masa lalu (tepatnya pada jaman Orde Baru) kini tergantikan dengan diperkenalkannya otonomi daerah, walaupun pekerjaan ini masih terus dijalankan, direvisi di sana-sini, sambil kita melihat juga fenomena makin banyak pemimpin daerah (walikota, bupati, atau gubernur) yang menjadi tersangka kasus korupsi di berbagai daerah. Tak pelak korupsi menjadi sesuatu yang terdesentralisasi juga. Dalam situasi ini, dimana posisi pers lokal? Apakah ia turut mengawal proses demokratisasi yang ada, ataukah ia turut menjadi bagian dari persoalan yang ada? Tepatnya apakah kita sedang berbicara peran pers lokal sebagai solusi dari masalah korupsi, ataukah pers lokal justru merupakan bagian dari masalah korupsi.

Dalam keriuhan pilkada di sejumlah tempat misalnya kita mendapati bagaimana pers lokal ikut dalam hiruk pikuk tersebut, bukan semata sebagai pemberi informasi, tetapi kerap kali menjadi partisan 
secara terselubung atas kandidat-kandidat tertentu. Salah satu misalnya adalah apa yang terjadi di Riau, sebagaimana ditulis oleh Nankyung Choi (2005). Sementara itu orang seperti Jack Snyder (2003) ketika bicara tentang negara-negara baru paska jatuhnya otoritarianisme, telah jauh-jauh hari mengingatkan, bagaimana peran dari media sebagai pembuat opini publik yang bisa menyokong kepentingan para nasionalis sempit, karena pada masa awal demokratisasi terjadi, suasana berpendapat bebas terjadi, pers lebih mudah didirikan,dan media bisa jadi alat bagi para maniak kekuasaan mengangkat kepentingannya. Kerap kali memang pers jatuh dalam nasionalisme sempit dimana pers menjadi agen untuk mengobarkan nasionalisme kesukuan (ethno-nationalism) sebagaimana dihembuskan sejumlah elit politik. Arah menuju ethno-nationalism di Indonesia dan sejumlah diskusi atas masalah konflik sosial dikemukakan oleh sejumlah peneliti, misalnya dalam buku yang diedit Edward Aspinall \& Greg Fealy, Power and Politics in Indonesia: Decentralisation and Democratisation (2003), juga pada karya Dewi Fortuna Anwar, Helene Bouvier, Glen Smith, \& Roger Tol, eds, Konflik Kekerasan Internal: Tinjauan Sejarah, Ekonomi, dan Kebijakan di Asia Pasifik (2004), juga dalam kajian berbagai peneliti dalam jurnal Indonesia milik Cornell University edisi 72 (Oktober 2001) dan edisi 73 (April 2002). Dan masih ada banyak lagi kajian lain soal dinamika otonomi daerah pasca reformasi tersebut.

Jika kita hubungkan desentralisasi ini dengan media, maka ketika pers sudah mencapai kebebasannya, setidaknya ia menanggung beberapa fungsi. Pertama, untuk menguatkan demokrasi (strethgning democracy), kedua meingkatkan kualitas pemerintahan (good govermance) (Mcquail, 2001). Sejalan dengan semangat desentralisasi yang juga mendemokratisasi ke seluruh wilayah, maka tidak hanya pers nasional, yang local pun berbanding lurus dengan keberadaan gelombang demokrasi di daerah. Juga karena pers nasional dan pers local masih tetap dalam bagian pers bebas.

Untuk itu, pers bebas perlu bersikap independen, responsive, dan akuntabel dalam mentransmisikan informasi kepada seluruh warga serta menyediakan keberagaman informasi guna memenuhi kebutuhan seluruh golongan di dalam kemajemukan warga (Norris, 2008). Oleh Norris (2008), fungsi dari pers bebas tersebut diderivatkan lagi menjadi tiga bagian. Sebagai bagian watchdog untuk pengawasan jika terjadi penyelahgunaan kekuasaan (promoting accountablility and transparency), sebagai forum public untuk diskursus politik, dan sebagai agenda setter untuk pembuat kebijakan. Fungsi-fungsi turunan tersebut selaras dengan pendapat Steiner (2004) untuk lebih mengembangkan lagi ruang-ruang diskursus politik guna mencapai demokrasi yang lebih terdeliberasi. Terutama fungsinya sebagai forum public. Dalam fungsinya sebagai penyedia forum public pers bebas mampu mengutamakan ruang public melalui menghubungkan antara warga dan Negara, menfasilitasi debat mengenai isu-isu public, dan memberikan informasi kepada public mengenai partai politik, isu-isu politik, serta kinerja pemerintahan. Khusus untuk pers local, ia bisa lebih mendekatkan lagi antara isu kebijakan, pemerintah, dan public itu sendiri. Apalagi 
ketika masa pemilu/pemilukada, perannya sangat diperlukan. Salama kampanye media sebaiknya menyedikan informasi public.

Terlebih ketika pers tersebut merupakan bagian dari suatu entitas atau komunitas tertentu ia akan bisa lebih dipercaya sebagai saluran informasi yang dipercaya. Identitas akan institusi pers tersebut melekat pada identitas warga. Atau memang dengan adanya pers tersebut identitas warga yang dilekatkan pada identitas institusi pers. Layaknya efek cermin. Potensi macam ini pernah disampaikan oleh Anderson (2001) bahwa surat kabar yang dikonsumsi masyarakat mampu menbentuk identitas suatu bangsa. Memang ia menyampaikan ada level nasion state. Tetapi ketika dipadukan dengan tesis yang disampikan Hariyanto (2011) tentang kemungkinan berkembangnya etnho-nationalism, menjadikan pembentukan identitas tersebut juga berlaku sangat efektif di level local.

Kedekatan identitas yang terjalin antara pers local dan masyarakat daerah itu sendiri saling berpilin. Berbeda dengan pers nasional bahkan pers internasional. Nilai-nilai yang dianut hingga segmentasi pun ditunjukkan untuk audiens yang luas. Memang benar, sekarang eranya globalisasi. Era yang membuat dunia semakin lebih dekat, berkat teknologi. Global village bukan lagi menjadi sesutau hal yang nisbi. Berita apapun dari media manapun bisa diakses. Namun, pikiran boleh mengglobal, tetapi lokasi hidup masih dilingkup daerah tertentu (local).

Maka untuk bisa menjalani kehidupan yang nyata di sekitar dibutuhkan informasi yang berasal dari daerah sekitar pula. Warga memerlukan informasi semisal untuk menolak atau mendukung kebijakan pembangunan hotel di daerahnya. Juga informasi mengenai track record pejabat publiknya. Begitu pula media lokal membutuhkan kedekatan identitas lokalitasnya sebagai pengabar yang dekat dengan warga, sehingga informasi yang disampaikan bisa dipercaya. Ujungnya adalah media lokal tersebut mampu bertahan hidup dan memperoleh keuntungan finansial dari warganya sekitar. Pola relasi inilah yang dibangun oleh warga di daerah dengan media lokalnya. Dilihat dari situ, media local merupakan saluran informasi public sekaligus pengawal demokrasi.

\section{PENUTUP}

Beragam peristiwa dan informasi yang sampai kepada masyarakat melalui media tidak terlepas dari peranan media massa dalam hubungannya dengan penyajian informasi dan cara media menginterpretasi suatu kejadian. Satu berita yang sampai kepada masyarakat akan memiliki banyak penafsiran dan tanggapan bergantung pada gaya bahasa (penyajian) dan cara penyampaiannya. Hal ini bisa saja dibumbui dengan gaya bahasa hiperbola untuk menarik minat pembaca berita dan mungkin juga berita yang disajikan telah terkontaminasi oleh opini dan subyektivitas penulis berita. Selalu ada kepentingan yang melatari cara manusia mengungkapkan suatu fakta ke dalam berita. Prinsip semiotika-seni berbohong-kadang bermain 
disini. Maka, keakuratan data dan keterpercayaan suatu berita harus dijunjung tinggi. Jika tidak, berita keliru yang tersebar akan berkembang menjadi opini publik yang juga keliru.

Selama ini media massa menjalankan fungsi sebagai pemegang otoritas public yang cukup besar. Selain itu, juga berperan sebagai medium penting dan pemegang kendali perubahan social yang tak kalah hebatnya disbanding isntitusi lain, seperti partai poltiik, birokrasi, dan lembaga-lembaga public lainnya. Media massa bukan seekdar memiliki peluang menyediakan informasi untuk ememnuhi hak untuk mengetahui (the right to know) dan hak untuk mengekspresiakn masyarakat. Lebih dari itu, media massa memegang otoritas yang besar dalam mebentuk imaji, mitos, perilaku, pengetahuan, bahkan ideology masyarakat.

Melalui proses penetapan agenda setting di tubuh organisasi media, maka system pengetahuan masyarakat mungkin saja dapat dikonstruk sebagaimana preferensi nilai dan ideology media itu sendiri. Dalam perpektif agenda setiing media, pola produksi teks yang hendak disebarkan kepada masyarakat sepenuhnya dikendalikan oleh internal organisasi media. organisasi medialah yang memiliki kuasa dalam menentukan mulai dari siapa wartawan yang harus diturunkan ke lapangan, narasumber mana yang harus diwawancarai, dan dari sisi mana sebuah realitas itu harus diangkat, serta phrasa idiomatika mapa apa yang harus dipilih untk mengungkapkan realitas bahkan sampai pada tataran mikro. Pola kontruksi semacam ini yang dikendalikan oleh media itulah apoa yang disebut McNair (1994) sebagai pola pendekatan organisasional.

Dalam mengkosnturksi realitas senyatanya tidak seluruh media tampil secara otonom. Bisa saja media mengkonstruksi atas darar tekanan eksternal, seperti tekanan politik. Pemegang monopoli kekerasan, pemilik modal, pemasang iklan, maupun kekuatan eksternal lainnya. Dengan kata lain, ekonomi politik pada posisi ini kemudian menjadi penting. Yaitu menjadi dasar pijakan media dalam mengkonstuksi realitas ke dalam ramuan redaksional. Pola teks di media semcama ini oleh McNair (1994) disebut sebagai pola pendekatan ekonomi politik.

Namun, sebagian media menyadari bahwa bersikap otonom sepenuhnya tidak mungkin, karena media tidak tumbuh dalam dunia yang vakum, tapi tumbuh dan berkembang dalam masyarakat dengan segala macam tingkat budaya yang diekspresikannya. Oleh karena itu, agar tetap eksis, media juga harus memeprtimbangkan imaji, mitos, tuntutan, kepentingan, bahkan tekanan dari masyarakat luas. Kalau factor eksternal ini tidak dipertimbangkanl maka media massa bisa jadi akan menghadapi resistensu dan represi masyarakat. Namun media juga tidak selayaknya meyerah sepenuhnya pada tekanan eksternal. Idelanya, meida massa mencoba untuk berdiri secara otonom namun tidak mengabaikan dan desakan public. Pola pendekatan semacam ini oleh McNair disebut sebagai pola kultural. 


\section{DAFTAR PUSTAKA}

Andersery Robin ed. (2000). Critical Studies in Media Commercialism. London: Oxford University Press

Herman, Edward S. dan Noam Chomsky. (1992). Manufacturing Consent, The Political Economy of The Mass Media. New York: Pantheon Books.

Jurnalisme Propaganda dan Gosip Meracuni Demokrasi. Kompas Online, Kamis, L1 Desember 2003

Kovack, Bill (2001). 9 Elements of lournalism. New York: The Rivers Press.

Luwarso, Lukas, ed. (2004). Media dan Pemilu 2004. Jakarta: Koalisi Media Untuk Pemilu Bebas dan Adil

Macmanus, John H. (1994). Market Driaen lournalism. London: Sage Publications

Mariani, Evi. (2001). 'Harian Rakjat Mengecam Resep jumalisme "orang Menggigit Anjing."' Pantau II No. 15 ]uli 2009

Masduki. (2004). 'Menyoal Fatwa Haram Presiden Perempuan.' Newsletter LP3Y, edisi 73 Mei.

McChesney, Robert (1998). Konglomerasi Media Massa dan Ancaman Terhadap Demokrasi. (terjemahan oleh Andi Achdian). Jakarta: Aliansi Jurnalis Independen.

McChesney, Robert. (1999). Rich Media, Poor Democracy: Communication Politics in Dubious Times. Illinois: University of Illinois Press.

McQuail, Denis (1994). Mass Communication Theory, Third Edition. London: Sage Publications

Meyer, Thomas (2002). Media DemouaW, How The Media Colonizt Politics. London: Polity Press

Nelson, Michael (ed). (2004). The Elections of 2004. Washington DC: Congressional Quarterly

Shoemaker, Pamela J. dan Reese, Stephen D. (1991)- Mediating the Message. Theories of Influences on Mass Media Content. New York: Longman Publishing

UU No. 40 Tahun 1999 Tentang Pers 